\title{
TINDAK PIDANA PERBANKAN BERDASARKAN UNDANG-UNDANG NOMOR 10 TAHUN 1998 TENTANG PERUBAHAN ATAS UNDANG- UNDANG NOMOR 7 TAHUN 1992 TENTANG PERBANKAN
}

\author{
L. Alfies sihombing, Yeni Nuraeni \\ fieslawfirm@gmail.com,yeni_nuraeni95@yahoo.com
}

Abstract

Not all articles of the banking law can ensnare perpetrators of criminal acts as regulated in Article 49 and Article 50 of Law No.10 of 1998 concerning Amendments to Law No.7 of 1992 concerning Banking, so as long as it is not regulated by This law can be applied to the Criminal Code (KUHP), such as criminal acts relating to documents or scripts forgery, so the provisions of Article 263 or Article 264 of the Criminal Code can be applied to regulate fraud, or embezzlement can be impo sed under article 372 of the Criminal Code which regulates embezzlement, Article 378 (fraud), Article 362 (theft). Given the banking function and strategic position as supporting the smooth payment system, implementing monetary policy and achieving financial system stability, it is necessary to have Good Corporate Governance, healthy, transparent banking institutions and uphold the principles of professionalism and compliance with applicable provisions and regulations which can subsequently minimizing criminal acts in the banking sector.

Key Word : Banking, regulation and criminal act

Abstrak

Tidak semua pasal-pasal dari undang-undang perbankan dapat menjerat pelaku tindak pidana sebagaimana diatur dalam Pasal 49 dan Pasal 50 Undang-Undang No.10 Tahun 1998 Tentang Perubahan atas Undang-undang No.7 Tahun 1992 Tentang Perbankan, maka sepanjang tidak diatur oleh Undang-undang ini dapat diterapkan Kitab Undang-Undang Hukum Pidana (KUHP), seperti tindak pidana yang berkaitan dengan tindakan pemalsuan dokumen atau warkat, maka dapat diberlakukan ketentuan Pasal 263 atau Pasal 264 KUHP yang mengatur pemalsuan surat, atau penggelapan dapat dikenakan pasal 372 KUHP yang mengatur tentang penggelapan, Pasal 378 (penipuan), Pasal 362 (pencurian). Mengingat fungsi perbankan dan kedudukan strategis sebagai penunjang kelancaran sistem pembayaran, pelaksanaan kebijakan moneter dan pencapaian stabilitas sistem keuangan, maka diperlukan adanya Good Corporate Governance, institusi perbankan yang sehat, transparan serta menjunjung tinggi azas profesionalisme dan kepatuhan terhadap ketentuan dan peraturan yang berlaku yang selanjutnya dapat meminimalisasi dilakukannya tindak pidana di bidang perbankan.

Kata kunci : Perbankan, Peraturan dan tindak Pidana.

\section{PENDAHULUAN}

Pemberitaan mengenai berbagai masalah yang melanda dunia perbankan di Indonesia senantiasa menarik perhatian masyarakat. Walaupun masyarakat mengalami masa-masa sulit dengan ditutupnya banyak bank dan kesulitan likuiditas yang dihadapi bank-bank pada beberapa tahun pertama dari krisis moneter, peran strategis perbankan dalam Pembangunan ekonomi tidak menyurut. Bagian terbesar dari perputaran uang tetap terjadi melalui pasar uang, kendati aktivitas pasar modal terus meningkat. Belajar dari 
pengalaman pahit dari krisis moneter, kiranya wajar apabila masyarakat berharap banyak akan makin baiknya pelaksanaan pengelolaan bank-bank di Indonesia.

Bank-bank seakan ditantang untuk dapat menunjukkan peran sebagai lembaga kepercayaan. Di lain pihak, fakta masih menunjukkan terjadinya berbagai tindak pidana perbankan yang setidaknya telah mencederai usaha-usaha serius untuk mengembalikan citra baik dunia perbankan di Indonesia. Bahwa pembangunan nasional yang dilaksanakan selama ini merupakan upaya pembangunan yang berkesinambungan yang meliputi seluruh aspek kehidupan dalam rangka mencapai tujuan nasional berdasarkan Pancasila dan Undang - Undang Dasar Negara Republik Indonesia Tahun 1945. Sehingga untuk mendukung terwujudnya pembangunan nasional yang berkesinambungan dan sejalan dengan tantangan perkembangan serta pembangunan ekonomi yang semakin kompetitif dan terintegrasi, maka kebijakan moneter harus dititik beratkan pada upaya untuk meningkatkan daya saing usaha yang lebih adil dan merata dengan menekankan pada peningkatan kesejahteran masyarakat.

Perkembangan ekonomi nasional dewasa ini menunjukkan arah yang semakin menyatu dengan ekonomi regional dan internasional yang dapat menunjang sekaligus dapat berdampak kurang menguntungkan. Sementara itu, perkembangan perekonomian nasional senantiasa bergerak cepat dengan tantangan yang semakin kompleks. Oleh karena itu, diperlukan berbagai penyesuaian kebijakan di bidang ekonomi termasuk sektor perbankan sehingga diharapkan akan dapat memperbaiki dan memperkukuh perekonomian nasional. Sektor perbankan yang memiliki posisi strategis sebagai lembaga intermediasi dan penunjang sistem perbankan merupakan faktor yang sangat menentukan dalam proses penyesuaian dimaksud. Sehubungan dengan itu, diperlukan penyempurnaan terhadap sistem perbankan nasional yang bukan hanya mencakup upaya penyehatan bank secara individual melainkan juga penyehatan sistem Perbankan secara menyeluruh. Upaya penyehatan Perbankan nasional menjadi tanggung jawab bersama antara Pemerintah, bank-bank itu sendiri dan masyarakat pengguna jasa bank.

Adanya tanggung jawab bersama tersebut dapat membantu memilihara tingkat kesehatan Perbankan nasional sehingga dapat berperan secara maksimal dalam perekonomian nasional.

Pembangunan hukum di Indonesia pada hakikatnya menuntut adanya perubahan sikap mental sedemikian rupa dan menghendaki agar hukum tidak lagi hanya dipandang sebagai perangkat norma semata, melainkan hukum dipandang juga sebagai sarana untuk mengubah masyarakat. Hukum tidak lagi berkembang dengan mengikuti masyarakat, melainkan hukum harus dapat memberikan arah kepada masyarakat sesuai dengan tahaptahap pembangunan yang dilaksanakan. ${ }^{1}$

Sehubungan dengan bertambahnya kebutuhan manusia yang tidak terbatas, dengan seiring pertumbuhan perekonomian yang tidak sehat, dapat menimbulkan suatu perekonomian Negara yang tidak stabil. Dalam dunia ekonomi muncullah suatu perbankan, dimana yang mempunyai tugas untuk menghimpun dana dari masyarakat dalam bentuk simpanan dan menyalurkan kepada masyarakat dalam bentuk kredit dan atau bentuk-bentuk

\footnotetext{
1 Muladi dan Dwidja Priyatno, Pertanggungjawaban Pidana Korporasi, Prenada Media Group, Jakarta, 2010,hlm.11.
} 
lain dalam rangka meningkatkan taraf hidup rakyat. Dalam perbankan yang paling besar jumlahnya adalah dalam bidang perkreditan atau penyaluran dana. Karena bank merupakan suatu usaha yang dengan tujuan lain adalah mencari keuntungan yang sebesar-besarnya, maka munculah suatu keserakahan dari seorang dari seorang kreditur untuk memberikan kredit kepada debitur sehingga akan memunculkan tindak pidana perbankan.

Salah satu contoh dalam tindak pidana perbankan yaitu pemberian kredit/pembiayaan tanpa disertai dengan analisis kredit yang professional dan atau tanpa memperhatikan asas-asas perkreditan atau pembiayaan berdasarkan prinsif syariah yang sehat, dan paling radikal dengan memberikan data-data fiktif penerima dana kredit dengan memunculkan debitur-debitur fiktif, sehingga berakibat suatu kredit bermasalah, bahkan sampai kepada kredit macet.

Dalam rangka menegakkan hukum di lingkungan perbankan dan mengamankan dana masyarakat serta kekayaan Negara yang ada pada bank, Bank Indonesia memandang perlu untuk melakukan koordinasi dengan dengan aparat penegak hukum dalam penanganan tindak pidana di bidang perbankan, sehingga pada tanggal 20 Desember 2004, Gubernur Bank Indonesia, Jaksa Agung RI dan Kapolri telah menandatangani Surat Keputusan Bersama (SKB) tentang Kerjasama Penanganan Tindak Pidana di Bidang Perbankan dan Petunjuk Pelaksanaannya sebagai pembaharuan dari SKB serupa yang telah ditandatangani pada tahun $1997 .^{2}$

\section{PEMBAHASAN}

Bila didefinisikan dari kejahatan bisnis dari beberapa literature dapat disimpulkan bahwa kejahatan bisnis yaitu kejahatan yang timbul dari praktek praktek bisnis, termasuk juga kejahatan perbankan termasuk didalamnya contoh dari kejahatan di dalam dunia bisnis. ${ }^{3}$ Sedangkan, bisnis itu merupakan salah satu aktivitas usaha yang utama dalam menunjang perkembangan ekonomi. Kata bisnis diambil dari bahasa Inggris "bussines" yang berarti kegiatan usaha. Istilah bisnis yang dimaksudkan adalah suatu urusan atau kegiatan dagang, industry atau keuangan yang dihubungkan dengan produksi atau pertukaran atau jasa.

Dengan menempatkan uang dari para entrepreneur dalam resiko tertentu dalam usaha tertentu dengan motif untuk mendapatkan keuntungan. Begitu juga dengan perbankan yang merupakan kegiatan usaha di bidang jasa yang tujuan utamanya mencari keuntungan, jadi dapat disimpulkan disini kejahatan perbankan merupakan bagian dari kejahatan bisnis. ${ }^{4}$ Pengertian kejahatan bisnis sendiri, dapatlah ditarik dari makna kata "kejahatan" dan "bisnis". Jadi kejahatan bisnis adalah suatu perbuatan yang dilarang oleh peraturan perundang-undangan dalam arti luas (hukum), bersifat melawan hukum dan diancam dengan hukuman pidana yang dilakukan baik oleh perorangan maupun perusahaan dalam aktivitas

\footnotetext{
${ }^{2}$ S.Sundari Arie, Tindak Pidana di Bidang Perbankan ditinjau dari Undang-Undang Perbankan dan Peraturan Perundang-undangan Terkait serta Permasalahan dalam Praktenya, makalah disampaikankan dalam seminar oleh CFISEL,2007, hlm 2.

${ }^{3}$ http://erwan29680.wordpress.com, dikunjungi pada tanggal 24 Agustus 2010.

4 Idem.
} 
Vol.1 No. 2 Juli 2019

perdagangan (bisnis) yang didalamnya meliputi pekerjaan, profesi, penghasilan, mata pencaharian dan keuntungan, dan lain-lain.

Dalam hal terjadinya suatu Tindak Pidana Perbankan yang dilakukan oleh orang dalam, terdapat beberapa undang-undang yang dapat diterapkan yaitu :

1. Kitab Undang-Undang Hukum Pidana (KUHP), ketentuan KUHP yang biasa dipakai misalnya Pasal 263 (pemalsuan), Pasal 372 (penggelapan dalam jabatan), Pasal 378 (penipuan), Pasal 362 (pencurian), dan lain-lain, maka pasal-pasal KUHP diterapkan biasanya apabila bank menjadi korban dari suatu tindak pidana.

2. Undang-Undang Pemberantasan Tindak Pidana Korupsi, diterapkan terhadap kasus-kasus yang menimpa bank pemerintah. Undang-Undang ini untuk mempermudahkan menjerat pelaku, mengenakan hukuman yang berat dan memperoleh uang pengganti atas kerugian Negara.

3. Undang-Undang No.10 Tahun 1998 Tentang Perubahan atas Undang-undang No.7 Tahun 1992 Tentang Perbankan, ketentuan dalam undang-undang ini biasanya diterapkan apabila komisaris, direksi, Pegawai dan pihak terafiliasi dengan bank (orang dalam) atau orang yang mengaku menjalankan usaha bank sendiri sebagai pelakunya.

Berkenaan dengan pasal-pasal mengenai tindak pidana perbankan, telah terjadi perubahan yang cukup signifikan yang terdapt di dalam Undang-Undang No.10 Tahun 1998 Tentang Perubahan atas Undang-undang No.7 Tahun 1992 Tentang Perbankan adalah mengenai pengenaan sanksi yang jauh lebih berat dan ditetapkan minimum dan maksimum dalam hal terjadi tindak pidana di bidang perbankan.

Tidak semua pasal-pasal dari undang-undang perbankan dapat menjerat pelaku tindak pidana sebagaimana diatur dalam Pasal 49 dan Pasal 50 Undang-Undang No.10 Tahun 1998 Tentang Perubahan atas Undang-undang No.7 Tahun 1992 Tentang Perbankan, maka sepanjang tidak diatur oleh Undang-undang ini dapat diterapkan Kitab Undang-Undang Hukum Pidana (KUHP), seperti tindak pidana yang berkaitan dengan tindakan pemalsuan dokumen atau warkat, maka dapat diberlakukan ketentuan Pasal 263 atau Pasal 264 KUHP yang mengatur pemalsuan surat, atau penggelapan dapat dikenakan pasal 372 KUHP yang mengatur tentang penggelapan, Pasal 378 (penipuan), Pasal 362 (pencurian).

Penanganan Kredit Bermasalah.

Bahwa salah satu kejahatan perbankan yang sering terjadi dan memiliki dampak yang luar biasa sesuai yang tercantum salah satunya di Undang-Undang No.10 Tahun 1998 Tentang Perubahan atas Undang-undang No.7 Tahun 1992 Tentang Perbankan satu kejahatan perbankan yang begitu sering terjadi yaitu adanya kredit bermasalah. Kredit bermasalah dalam jumlah besar dapat mendatangkan dampak yang tidak menguntungkan bagi bank pemberi kredit, dunia perbankan pada umumnya, dan juga terhadap kehidupan ekonomi dan moneter dalam suatu Negara. ${ }^{5}$ Melihat dampak yang sedemikian besar terhadap kredit

\footnotetext{
${ }^{5}$ Siswanto Sutojo, Mengenai Kredit Bermasalah, Jakarta :Damar Mulia Pustaka, 2008, hlm 25.
} 


\section{Res Nullius}

Law Journal

Vol.1 No. 2 Juli 2019

bermasalah, maka hal tersebut harus segera ditangani. Dalam penanganan kredit bermasalah adalah kecepatan pengembalian biaya yang seminimal mungkin menjadi bagian yang tidak dapat terpisahkan dalam upaya bank mengatasi permasalahan kredit bermasalah. ${ }^{6}$

Hal-hal yang perlu diperhatikan dalam penanganan kredit bermasalah adalah :

- $\quad$ Keinginan debitur untuk menyelesaikan kewajiban.

- $\quad$ Tingkat kerja sama dan keterbukaan debitur.

- Kemampuan financial debitur.

- $\quad$ Sumber pengembalian pinjaman.

- $\quad$ Prospek usaha debitur.

- Mudah tidakya menjual jaminan.

- Kelengkapan dokumentasi jaminan.

- Ada tidaknya tambahan jaminan baru.

- $\quad$ Sengketa tidaknya jaminan.

- Ada tidaknya sumber pembayaran dari usaha lain.

Menurut Siswanto Sutojo dalam menangani kredit bermasalah, pimpinan bank harus tetap berpegang pada pedoman pokok penanganan kredit bermasalah, yaitu usaha penyelamatan kredit tersebut dapat ditempuh dengan dua cara, yaitu melalui jalur hukum maupun jalur nonhukum. Salah satu upaya penyelamatan kredit melalui jalur nonhukum adalah restrukturisasi kredit. Dasar hukum restrukturisasi kredit adalah Surat Direksi Bank Indonesia No.31/150/KEP/DIR tanggal 12 November 1998.

Restrukturisasi merupakan upaya yang dilakukan Bank dalam rangka membantu nasabah agar dapat menyelesaikan kewajibannya, antara lain melalui :

1. Penjadwalan kembali (rescheduling), yaitu perubahan jadwal pembayaran kewajiban nasabah atau jangka waktunya. Tindakan rescheduling dapat diberikan kepada debitur yang masih menunjukkan itikad baik untuk melunasi kewajibannya. Faktor-faktor yang mendukung diberikannya tindakan rescheduling misalnya : pemasaran dari produk debitur masih baik, yang dihasilkan oleh mesin/pabrik/proses produksi yang masih berjalan normal. Dari sisi aspek manajemen, usaha debitur dikelola oleh tenaga yang professional dan cukup terampil. Bahan baku untuk keperluan produksi debitur cukup tersedia di pasar, sedangkan proses produksinya menggunakan metode teknologi yang memadai (tidak usang/belum out of date). Di samping itu, peraturan pemerintah dan kondisi ekonomi global cukup mendukung. Tindakan rescheduling ini dilakukan karena terjadi kelebihan pembiayaan terhadap objek kredit (over finance). Agunan yang dikuasai bank cukup mengatasi dan memenuhi syarat yuridis.

2. Persyaratan kembali (reconditioning), yaitu perubahan sebagian atau seluruh persyaratan Pembiayaan, antara lain perubahan jadwal pembayaran, jumlah angsuran, jangka waktu dan/atau pemberian potongan sepanjang tidak menambah sisa kewajiban nasabah yang harus dibayarkan kepada bank. Tindakan reconditioning dapat diberikan kepada debitur yang masih memiliki itikad baik untuk melunasi kewajibannya, yang berdasarkan

\footnotetext{
6 Idem, hlm 25.
} 
Vol.1 No. 2 Juli 2019

pembuktian secara kuantitatif merupakan alternative yang terbaik. Mesin/pabrik/proses produksi masih berfungsi baik dan terawat, kapasitas masih dapat ditingkatkan. Usaha debitur dikelola oleh manajemen yang professional dan menggunakan tenaga kerja yang cukup terampil. Untuk kelangsungan produksinya, debitur tidak mengalami kesulitan untuk mendapatkan bahan baku, dan berproduksi dengan memakai teknologi yang memadai, peraturan pemerintah dan kondisi ekonomi global cukup mendukung. Tindakan reconditioning ini dilakukan karena debitur mengalami kekurangan modal kerja. Agunan yang dikuasai bank cukup mengatasi dan memenuhi syarat yuridis.

3. Penataan kembali (restructuring), yaitu perubahan persyaratan pembiayaan tidak terbatas pada rescheduling atau reconditioning. Restrukturisasi kredit hanya dapat dilakukan atas dasar permohonan secara tertulis dari nasabah. Restrukturisasi kredit hanya dapat dilakukan untuk nasabah yang memenuhi criteria sebagai berikut :

a. Nasabah mengalami penurunan kemampuan pembayaran.

b. Nasabah memiliki prospek usaha yang baik dan mampu memenuhi kewajiban setelah restrukturisasi.

Penyelesaian kredit melalui institusi hukum dapat dilakukan melalui pendekatan litigasi (jalur pengadilan) dan pendekatan nonlitigasi (di luar pengadilan). Pendekatan litigasi akan menyerap biaya yang cukup besar serta memakan waktu yang cukup lama karena adanya proses hukum. Sedangkan pendekatan nonlitigasi menyerap biaya yang relative lebih kecil serta memakan waktu yang relative lebih singkat. Upaya penyelesaian nonlitigasi dapat ditempuh melalui proses mediasi yang akhir-akhir ini sedang dikampanyekan oleh Bank Indonesia dan sedang laris manis digunakan oleh bank dalam menyelesaikan sengketa terhadap nasabahnya. berikut :

Penyelamatan kredit melalui jalur litigasi dapat dilakukan melalui badan-badan sebagai

1. Somasi (surat peringatan utang).

2. Gugatan kepada debitur melalui pengadilan negeri Uitvoer Bij Voorad.

3. Eksekusi putusan pengadilan.

4. Eksekusi akta pengakuan utang.

5. Eksekusi hak tanggungan.

6. Parate Eksekusi Hak Tanggungan.

7. Eksekusi Terhadap Penjamin.

8. Lembaga Paksa Badan.

9. Kepailitan melalui Pengadilan Niaga.

Penegakan Hukum Kejahatan Perbankan.

Dalam rangka menegakkan hukum di lingkungan perbankan dan mengamankan dana masyarakat serta kekayaan Negara yang ada pada bank, Bank Indonesia memandang perlu untuk melakukan koordinasi dengan aparat penegak hukum dalam penanganan tindak pidana di bidang perbankan, sehingga pada tanggal 20 Desember 2004, Gubernur Bank Indonesia, Jaksa Agung RI dan Kapolri telah menandatangani Surat Keputusan Bersama (SKB) tentang 
Vol.1 No. 2 Juli 2019

Kerjasama Penanganan Tindak Pidana di Bidang Perbankan dan Petunjuk Pelaksanaannya sebagai pembaharuan dari SKB serupa yang telah ditandatangani pada tahun 1997.

Bahkan Menteri Koordinator Bidang Perekonomian dengan surat No.S241/M.EKON/10/2005 tanggal 20 Oktober 2005 kepada Presiden RI menginformasikan bahwa Bank Indonesia, Kejaksaan RI dan Kepolisian Negara RI sepakat penyelesaian dugaan tindak pidana perbankan tetap mengacu pada SKB tersebut. Dengan demikian segala sesuatu penyelidikan lanjutan hanya dapat dilakukan setelah dilakukan penyelidikan awal dari Bank Indonesia, hal ini untuk menghindari kekhawatiran dari petugas bank terhadap pemanggilan berturut-turut karena masalah yang belum jelas.

Mengingat fungsi perbankan dan kedudukan strategis sebagai penunjang kelancaran sistem pembayaran, pelaksanaan kebijakan moneter dan pencapaian stabilitas sistem keuangan, maka diperlukan adanya Good Corporate Governance, institusi perbankan yang sehat, transparan serta menjunjung tinggi azas profesionalisme dan kepatuhan terhadap ketentuan dan peraturan yang berlaku yang selanjutnya dapat meminimalisasi dilakukannya tindak pidana di bidang perbankan. Sehubungan dengan tindak pidana di bidang perbankan tersebut, Undang - undang No.7 Tahun 1992 tentang Perbankan sebagaimana diubah dengan Undang-undang No. 10 Tahun 1998 (UU Perbankan) memberikan cakupan yang jelas tentang tindak pidana di bidang perbangkan.

Selain itu, ketentuan-ketentuan yang terkait tentang tindak pidana di bidang perbankan tersebut diatur dalam ketentuan peraturan perundang-undangan antara lain sebagai berikut :

a. Undang-undang No. 8 Tahun 1995 tentang Pasar Modal.

b. Undang-undang No.31 tahun 1999 tentang Pemberantasan Tindak Pidana Korupsi sebagaimana telah diubah dengan Undang-Undang No.20 tahun 2001 tentang Korupsi.Undang-undang No.15 tahun 2002 tentang Tindak Pidana Pencucian Uang sebagaimana telah diubah dengan Undang-undang No.25 tahun 2003 (UU TPPU).

c. Undang-undang No.23 tahun 1999 tentang Bank Indonesia sebagaimana diubah dengan Undang-undang No.3 tahun 2004 (UU Bank Indonesia).

d. Undang-undang No.24 tahun 1999 tentang Lalu Lintas Devisa (UU LLD).

e. Kitab Undang-undang Hukum Pidana (KUHP).

Penanganan Dugaan Tindak Pidana Perbankan. sebagai berikut :

Pengaturan dan pengawasan bank oleh Bank Indonesia meliputi wewenang

1. Memberikan dan mencabut izin usaha bank (right to license).

2. Menetapkan peraturan dalam bidang perbankan (right to regulate).

3. Melakukan pengawasan terhadap bank(right to control).

4. Mengenakan sanksi terhadap bank yang melanggar ketentuan perbankan (right to impose sanction). Hal tersebut sejalan dan sesuai dengan amanat dalam Undang-Undang Perbankan. Oleh karena itu, dalam pelaksanaan 
kewenangan yan dimilikinya, Bank Indonesia mengacu kepada UndangUndang Perbankan tersebut.

Dalam rangka melakukan tindakan represif terhadap pelanggaran ketentuan yang berlaku, khususnya yang mengandung unsur tindak pidana di bidang perbankan, dibentuk Tim Investigasi Penyimpangan di Bidang Perbankan (TIPPER) berdasarkan SK Direksi Bank Indonesia No.31/181/KEP/DIR tanggal 31 Desember 1998, yang kemudian diubah menjadi unit Khusus Investigasi Perbankan (UKIP) sesuai peraturan Dewan Gubernur (PDG) Bank Indonesia No.3/1/PDG/2001 tanggal 27 April 2001 tentang Organisasi Sektor Perbankan dan terakhir diubah menjadi Direktorat Investigasi dan Mediasi Perbankan(DIMP) berdasarkan PDG Bank Indonesia No.7/29/PDG/2005 tanggal 12 Desember 2005 tentang Perubahan kelima atas PDG No.3/1/PDG/2001 Tentang Organisasi Sektor Perbankan.

DIMP memiliki misi melakukan tindak lanjut terhadap temuan pengawasan, pemeriksaan dan atau laporan/informasi mengenai penyimpangan yang diduga mengandung unsur pidana di bidang perbankan serta melaksanakan fungsi mediasi terhadap sengketa antara bank dengan nasabah yang mengacu pada prinsip good corporate governance dalam rangka mencapai sistem perbankan yang sehat guna mendukung kestabilan sisitem keuangan. Pembentukan DIMP diharapkan dapat mendukung announcement effect terhadap dunia perbankan yaitu law enforcement dalam kegiatan perbankan tetap dilaksanakan dan ditegakkan serta segala bentuk penyimpangan yang dilakukan akan membawa konsekuensi hukum bagi para pelakunya.

Dengan demikian adanya pembentukan DIMP ini dapat memfasilitasi masyarakat atau stakeholders yang ingin memberikan laporan/informasi adanya dugaan tindak pidana di bidang perbankan kepada Bank Indonesia sehingga selanjutnya bank Indonesia dapat menindaklanjuti laporan/informasi tersebut untuk menemukan kebenaran adanya dugaan tindak pidana di bidang perbankan.

Tindak Pidana Di Bidang Perbankan.

Dalam Undang-undang perbankan, tidak disebutkan secara tegas batasan dan jenis tindak pidana di bidang perbankan. Namun apabila dilihat dari berbagai literatur dan peraturan perundang-undangan yang berlaku, tindak pidana di bidang perbankan dapat diartikan sebagai tindak pidana sebagaimana diatur dalam pasal 46 sampai dengan pasal 50A Undang-undang Perbankan yang secara garis besarnya dapat dikelompokkan menjadi beberapa jenis yaitu :

1. Tindak Pidana yang berkaitan dengan perijinan (Pasal 46 jo pasal 16). Perijinan bagi setiap pihak yang melakukan kegiatan menghimpun dana dari masyarakat merupakan suatu hal yang sangat penting untuk diawasi.

2. Tindak pidana yang berkaitan dengan rahasia bank (Pasal 40, 41, 41A , 42,42 A , 43 , 44, 44 A , 45, 47 \& 47 A). Ketentuan rahasia bank diperlukan untuk menjaga kepercayaan masyarakat agar informasi nasabah penyimpan dan simpanannya tidak disalahgunakan demi menjamin kelangsungan usaha bank, sehingga keberadaan rahasia bank sangat strategis. 
3. Tindak pidana yang berkaitan dengan pengawasan bank oleh Bank Indonesia (Pasal 29, 30 \& 48). Dalam rangka pengawasan bank oleh bank Indonesia, bank wajib menyampaikan kepada Bank Indonesia segala keterangan dan penjelasan mengenai usahanya, memberikan kesempatan bagi pemeriksaan buku-buku dan berkas-berkas yang ada pada bank serta menyampaikan laporan-laporan dalam waktu dan bentuk yang ditetapkan oleh Bank Indonesia.

4. Tindak pidana yang berkaitan dengan kegiatan usaha Bank (Pasal 49 ayat $1 \& 2$ ). Dalam menjalankan fungsinya, Bank dapat melakukan berbagai kegiatan usaha yang meliputi penghimpunan dana, penyaluran kredit/pembiayaan dan penyediaan jasa lainnya seperti transfer, penjualan dan pembelian travel cek dan L/C.

5. Tindak pidana terkait dengan pihak terafiliasi (Pasal 50) Undang-undang perbankan tidak hanya mengatur kewajiban pengurus dan pegawai bank tetapi juga pihak terafliasi, yang meliputi pengurus dan pegawai bank baik yang berbentuk perseroan terbatas maupun koperasi, pihak yang memberikan jasanya kepada bank antara lain akuntan public, konsultan hukum, penilai dan lain-lain dan pihak yang menurut penilaian Bank Indonesia turut serta mempengaruhi pengelolaan Bank antara lain pemegang saham dan keluarga pengurus bank.

6. Tindak pidana yang terkait dengan pemegang Saham (Pasal 50A) pemegang saham bank yang dikenal dengan istilah pemilk bank juga diancam denagn sanksi pidana apabila menyuruh Komisaris, Direksi dan pegawai bank untuk melakukan tindakan melawan hukum.

Hambatan dan tantangan dalam penanganan kejahatan perbankan.

Bahwa penanggulangan kejahatan perbankan begitu kompleks permasalahannya sehingga proses penanganan kejahatan Perbankan mengalami kendala dan hambatan baik di Bank Indonesia dan Aparat penegak Hukum diantaranya :

a. Bank Indonesia.

1. Sistem kontrol yang dilakukan oleh Bank Indonesia tidak begitu ketat sehingga masih memberikan peluang bagi oknum-oknum memanfaatkan celah tersebut.

2. Lemahnya pegontrolan Bank Indonesia dalam pengeluaran sertifikat Bank.

3. Kemudahan dalam transaksi perbankan antar bank di berbagai Negara.

4. Mudahnya melakukan transaksi dengan menggunakan E-Bankin melalui internet.

5. Teknologi security di Bank atau perdagangan valas yang tertinggal.

6. Sistem control terhadap perdagangan valuta asing dan pendirian perusahaan masih lemah.

b. Aparat penegak hukum :

1. Aparat penegak hukum kurang professional (menjalankan pekerjaannya secara benar dan tidak menyimpang dari kode etik profesi masing-masing) dan independen (tidak diintervensi oleh pihak manapun dan tidak membawa kepentingan pihak tertentu).

2. Secara kuantitatif, penyidik tindak pidana ekonomi masih kurang, apalagi setelah era reformasi, tindak pidana ekonomi semakin meningkat. 
Vol.1 No. 2 Juli 2019

3. Lemahnya penguasaan perundang-undangan ekonomi oleh aparat penegak hukum, serta tidak konsistennya aparat dalam mengikuti perkembangan kejahatan di bidang perbankan dan valuta asing.

4. Terbatasnya personil yang mengawaki teknologi informatika, yang berhubngan dengan proses penyidikan.

5. Dalam pelaksanaan penyidikan masih bersifat reaktif, sehingga apabila tidak ada laporan perihal kejahatan kerah putih, maka anggota pasif saja.

6. Masih didapatinya praktek KKN dalam pelaksanaan penyidikan tindak pidana ekonomi. $^{7}$

\section{KESIMPULAN}

Bahwa kejahatan Perbankan yang sering dan bisa muncul kepermukaan dapat disebabkan oleh Error Omission (EO) adalah kejahatan perbankan yang timbul oleh adanya unsur kesengajaan untuk melanggar kebijakan dan prosedur yang telah ditetapkan, baik oleh pemberi pinjaman (Bank/Kreditur) atau penerima pinjaman(Nasabah/debitur) dan selanjtnya Error Commusion (EC) timbulnya kejahatan perbankan karena memanfaatkan lemahnya peraturan atau ketentuan yaitu memang belum ada atau sudah ada, tetapi tidak jelas.

Dalam rangka melakukan tindakan represif terhadap pelanggaran ketentuan yang berlaku, khususnya yang mengandung unsur tindak pidana di bidang perbankan, dibentuk Tim Investigasi Penyimpangan di Bidang Perbankan (TIPPER) berdasarkan SK Direksi Bank Indonesia No.31/181/KEP/DIR tanggal 31 Desember 1998, yang kemudian diubah menjadi unit Khusus Investigasi Perbankan (UKIP) sesuai peraturan Dewan Gubernur (PDG) Bank Indonesia No.3/1/PDG/2001 tanggal 27 April 2001 tentang Organisasi Sektor Perbankan dan terakhir diubah menjadi Direktorat Investigasi dan Mediasi Perbankan(DIMP) berdasarkan PDG Bank Indonesia No.7/29/PDG/2005 tanggal 12 Desember 2005 tentang Perubahan kelima atas PDG No.3/1/PDG/2001 Tentang Organisasi Sektor Perbankan.

DIMP memiliki misi melakukan tindak lanjut terhadap temuan pengawasan, pemeriksaan dan atau laporan/informasi mengenai penyimpangan yang diduga mengandung unsur pidana di bidang perbankan serta melaksanakan fungsi mediasi terhadap sengketa antara bank dengan nasabah yang mengacu pada prinsip good corporate governance dalam rangka mencapai sistem perbankan yang sehat guna mendukung kestabilan sisitem keuangan.

Pembentukan DIMP diharapkan dapat mendukung announcement effect terhadap dunia perbankan yaitu law enforcement dalam kegiatan perbankan tetap dilaksanakan dan ditegakkan serta segala bentuk penyimpangan yang dilakukan akan membawa konsekuensi hukum bagi para pelakunya.

Dengan demikian adanya pembentukan DIMP ini dapat memfasilitasi masyarakat atau stakeholders yang ingin memberikan laporan/informasi adanya dugaan tindak pidana di

\footnotetext{
${ }^{7}$ Sambudiyono, Antisipasi dan Strategi Polri Dalam Menaggulangi Kejahatan Kerah Putih Guna Mendukung Kelangsungan Pembangunan Nasional Dan Mewujudkan Keamanan Dalam Negeri, makalah, Lembang, 2007.
} 


\section{Res Nullius}

Law Journal

Vol.1 No. 2 Juli 2019

bidang perbankan kepada Bank Indonesia sehingga selanjutnya bank Indonesia dapat menindaklanjuti laporan/informasi tersebut untuk menemukan kebenaran adanya dugaan tindak pidana di bidang perbankan.

Oleh karena itu dari semua uraian diatas dapat ditarik kesimpulan sebagai berikut :

1. Tindak Pidana di bidang perbankan adalah tindak pidana yang merugikan kepentingan berbagai pihak baik bank sendiri selaku badan usaha, nasabah, penyimpan dana, sistem perbankan, otoritas perbankan, Negara dan pemerintah serta masyarakat luas.

2. Besarnya asset yang dikelola oleh perbankan, pesatnya perkembangan produk dan penggunaan Information Technology (IT) di bidang perbankan dapat memberikan peluang terjadinya penyimpangan di bidang perbankan, sehingga bank sering digunakan sebagai sarana dan sasaran tindak pidana di bidang perbankan, tindak pidana korupsi dan tindak pidana pencucin uang.

3. Dampak penyimpangan atau tindak pidana di bidang perbankan tersebut di samping dapat menurunkan tingkat kepercayaan masyarakat terhadap dunia perbankan, juga menimbulkan kerugian financial yang cukup besar jumlahnya secara kumulatif.

4. Tindak pidana perbankan yang dilakukan oleh pejabat atau pihak terafiliasi Bank yang memenuhi seluruh unsur-unsur tindak pidana korupsi juga dapat diindikasikan sebagai tindak pidana korupsi. Untuk kasus-kasus semacam ini, di samping dituntut sebagai tindak pidana korupsi hendaknya juga ditambahkan tuntutan tindak pidana perbankan sepanjang telah melanggar ketentuan pidana perbankan yang didukung dengan alat bukti dan fakta yuridis yang kuat.

5. Sesuai prinsip-prinsip dalam hukum perseroan dan hukum perbankan, pengurus bank (Komisaris dan Direksi) wajib bertanggung jawab atas pelaksanaan operasional bank termasuk penyimpangan yang mengandung unsur pidana melalui sistem pemantauan dan pengawasan operasional perbankan (management liability) dan berdasarkan peraturan perundang-undangan yang berlaku tindak pidana di bidang perbankan (pemilik/pemegang saham, pengurus atau pegawai bank) harus bertanggung jawab atas penyimpangan perbankan yang memenuhi unsur tindak pidana di bidang perbankan (criminal liability).

6. Penegakan hukum (law enforcement) merupakan reaksi hukum terhadap terjadinya pelanggaran ketentuan perbankan dengan tujuan pelaku yang telah merugikan perbankan dan simpanan masyarakat, dijatuhi hukuman yang adil dan setimpal sesuai dengan besarnya kerugian bank dan Negara serta dapat tercipta kepastian hukum bagi masyarakat.

7. Di samping itu penegakan hukum dimaksudkan agar terciptanya ketertiban dan keteraturan dalam pelaksanaan ketentuan perbankan.

\section{DAFTAR PUSTAKA}

Muladi, Dwidja Priyatno, Pertanggungjawaban Pidana Korporasi, Prenada Media Group, Jakarta, 2010.

S.Sundari Arie, Tindak Pidana di Bidang Perbankan ditinjau dari Undang-Undang Perbankan dan Peraturan Perundang-undangan Terkait serta Permasalahan dalam Praktenya, makalah disampaikankan dalam seminar oleh CFISEL,2007. 
Vol.1 No. 2 Juli 2019

Tim Citra Umbara, Undang-Undang RI Nomor 6 Tahun 2009 tentang Bank Indonesia \& Undang-Undang RI Nomor 21 Tahun 2008 tentang Perbankan Syariah, Citra Umbara, Bandung, 2009.

Moeljatno, Kitab Undang-Undang Hukum Pidana, Bumi Aksara, Jakarta,2001.

Samuel Purwito Heri Prasetyo, Tinjauan Hukum Pidana terhadap Kredit Macet Di Bank Berdasarkan Undang-Undang Nomor 10 Tahun 1998,http/sinta.uns.ac.id, dikunjungi 1 Mei 2010.

Ahmad Fikri Assegaf, Tindak Pidana Perbankan \& Penerapan Undang-undang Korupsi Dalam Kasus-Kasus Perbankan, diselenggarakan oleh Center For Finance And Securities Law, diselenggarakan di Hotel Mandarin Oriental, Jakarta, tanggal 31 Mei 2006.

Direktorat Perizinan dan Informasi Perbankan, Booklet Perbankan Indonesia, Bank Indonesia, Jakarta, 2009.

Badriyah Harun, Penyelesaian Sengketa Kredit Bermasalah, Pustaka Yustisia, Yogyakarta, 2010.

Siswanto Sutojo, Mengenai Kredit Bermasalah Jakarta :Damar Mulia Pustaka, 2008.

Sambudiyono, Antisipasi dan Strategi Polri Dalam Menaggulangi Kejahatan Kerah Puth Guna Mendukung Kelangsungan Pembangunan Nasional Dan Mewujudkan Keamanan Dalam Negeri, makalah, Lembang 2007.

Sumber Internet

http://erwan29680.wordpress.com, dikunjungi pada tanggal 24 Agustus 2010. 